\title{
Design of indole- and MCR-based macrocycles as p53-MDM2 antagonists
}

\author{
Constantinos G. Neochoritis ${ }^{1}$, Maryam Kazemi Miraki², Eman M. M. Abdelraheem¹, \\ Ewa Surmiak $^{3}$, Tryfon Zarganes-Tzitzikas ${ }^{1}$, Beata Łabuzek ${ }^{3}$, Tad A. Holak ${ }^{3}$ \\ and Alexander Dömling ${ }^{* 1}$
}

\section{Full Research Paper}

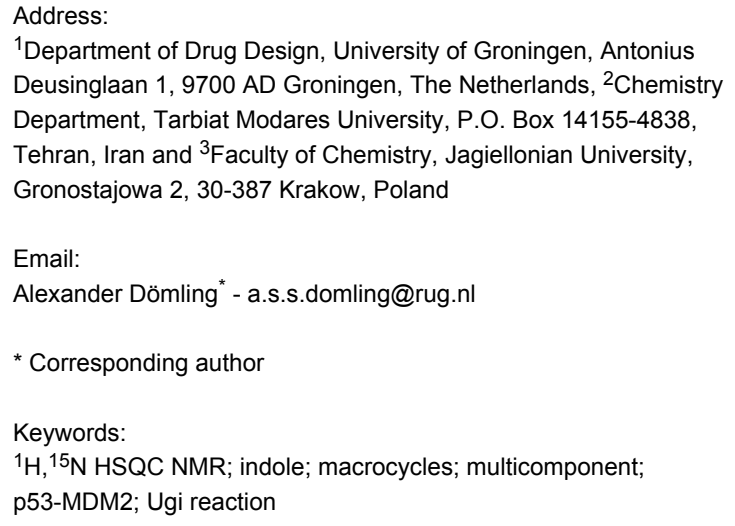

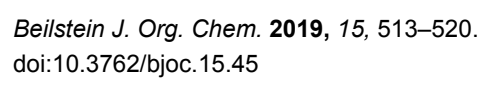

\begin{abstract}
Macrocycles were designed to antagonize the protein-protein interaction p53-MDM2 based on the three-finger pharmacophore $\mathrm{F}^{19} \mathrm{~W}^{23} \mathrm{~L}^{25}$. The synthesis was accomplished by a rapid, one-pot synthesis of indole-based macrocycles based on Ugi macrocyclization. The reaction of 12 different $\alpha, \omega$-amino acids and different indole-3-carboxaldehyde derivatives afforded a unique library of macrocycles otherwise difficult to access. Screening of the library for p53-MDM2 inhibition by fluorescence polarization and ${ }^{1} \mathrm{H},{ }^{15} \mathrm{~N}$ HSQC NMR measurements confirm MDM2 binding.
\end{abstract}

\section{Introduction}

Macrocycles are the chemical entities that are consisting of a 12 -membered or even bigger ring. It is estimated that $3 \%$ of the known natural products consists of a macrocyclic ring [1-5]. Compared to macrocycles in synthetic molecules, the aforementioned occurrence is still over proportional; for that reason, these compounds have delighted scientists worldwide due to their special physicochemical properties, their roles in biological systems and the associated synthetic challenges [6,7]. However, only few synthetic methods allow for the convergent and fast access to a large macrocyclic chemical space [8-10]; most of the times their synthesis is complex, multistep and sequential $[11,12]$. For this reason a great effort is ongoing to utilize multicomponent reactions for the synthesis of macrocycles [8,13-25].

The p53 protein is a well-studied protein which has a leading role in protecting our organism from cancer. It was found that most of the human cancers have either mutated the p53 itself or the p53 pathway is inhibited. The latter group of tumors retains the wild type p53 (wt-p53) but its pathway is inactivated by 
negative regulators, mainly the MDM2 and MDMX proteins. Thus, the design and synthesis of an inhibitor of the MDM2-p53 interaction could enable p53 and reverse tumor formation [26-28]. Based on our knowledge to antagonize the oncogenic protein-protein interaction p53-MDM2 [23,29-40] we designed macrocyclic inhibitors in continuation of our previous work [13,23]. Herein, an indole-based macrocycle synthesis is reported in a one-pot fashion based on Ugi macrocyclization with readily available $\alpha, \omega$-amino acids. Moreover, in continuation of our efforts in the design and synthesis of macrocycles targeting the p53-MDM2 interaction demonstrating the potential of these indole-based macrocycles, a subset of them was screened searching for MDM2 inhibitors. Compared to our previous indole-based macrocycles 1 following a different strategy (employing a classical Ugi-4C as the key reaction) [23], this one-pot Ugi macrocyclization leading to macrocycles 2 offers speed (one-pot procedure with one purification step), much better yields, no need of expensive catalysts as in ring-closing metathesis (RCM) reaction and higher complexity/diversity on the macrocyclic ring, e.g., insertion of heteroatoms that could improve the ADMET properties (Scheme 1) [4].

\section{Results and Discussion Synthesis}

Based on our previous studies [13], unprotected diamines 3 were reacted in one-step with cyclic anhydrides $\mathbf{4}$ at $\mathrm{rt}$ affording the appropriate $\alpha, \omega$-amino acids $\mathbf{5}$ in excellent yields (see Supporting Information File 1). Elongated diamines ( $n=2-4,6,8$ and 10) and cyclic anhydrides that bear a heteroatom in the 4-position as oxygen or sulfur ( $\mathrm{Y}=\mathrm{O}, \mathrm{S}$, Scheme 2) were employed in order to enhance the diversity of our macrocycles [4]. Thus, in a parallel way, we readily synthesized 12 different amino acids which were subsequently subjected to the Ugi macrocyclization.

After quite some optimization, we improved the Ugi-macrocyclization procedure compared to our previous findings utilizing microwave irradiation (see Supporting Information File 1); Firstly, the corresponding amino acid was irradiated with indole-3-carboxaldehyde derivatives 6 using $\mathrm{MeOH}$ as solvent $(5 \mathrm{~mL})$ at $120{ }^{\circ} \mathrm{C}$ for $1 \mathrm{~h}$. Then, tert-butyl isocyanide was added, diluted with more $\mathrm{MeOH}$ and irradiated again the reaction mixture at $120{ }^{\circ} \mathrm{C}$ for an additional $1 \mathrm{~h}$ in a final concentration of $0.1 \mathrm{M}$ (Scheme 3). By this way, a rapid, one-<smiles>[X]c1ccc(CN)cc1</smiles>

Scheme 1: MCR approach to indole-based macrocycles; a more effective strategy is proposed in this work, based on a, $\omega$-amino acids and an Ugi macrocyclization.
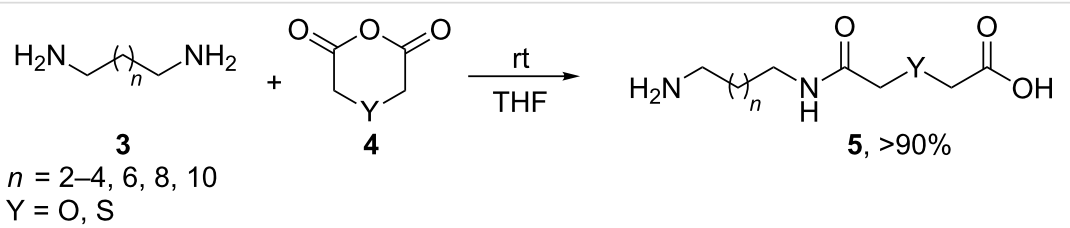

$5,>90 \%$ 


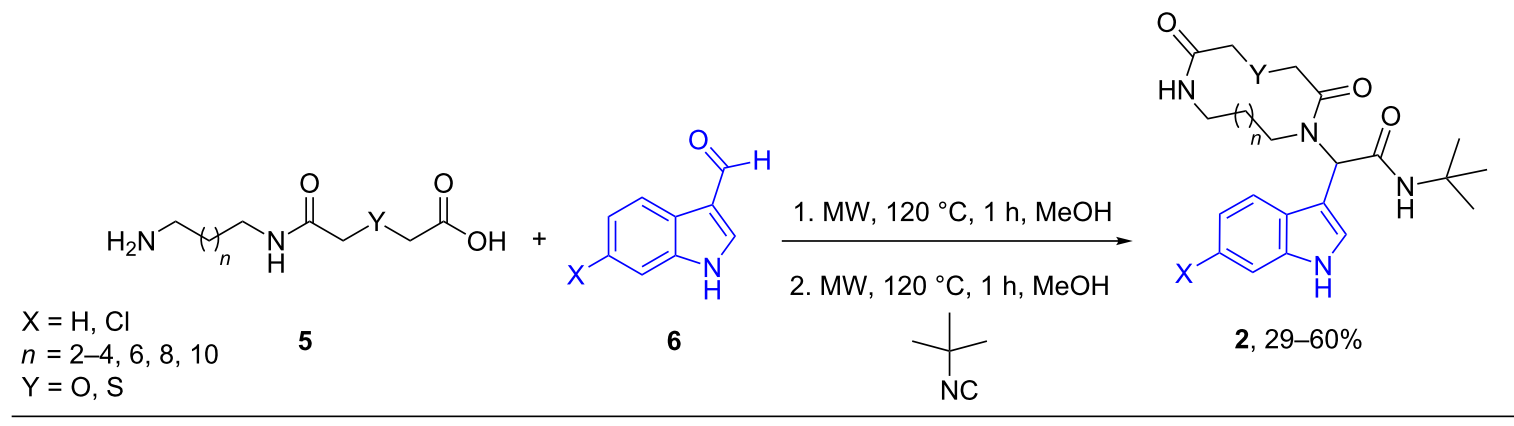

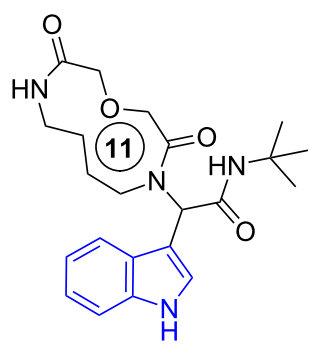

2a, $40 \%$

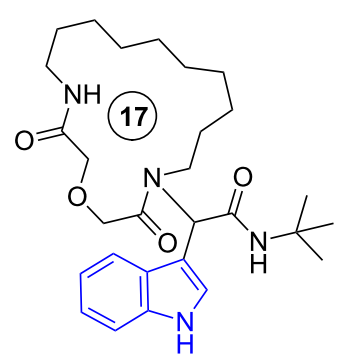

2e, $31 \%$

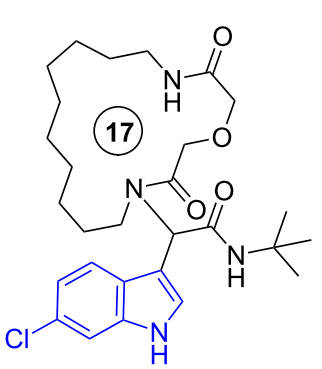

2i, $51 \%$

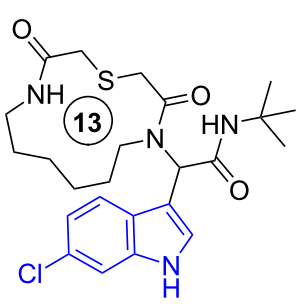

$2 \mathrm{~m}, 39 \%$

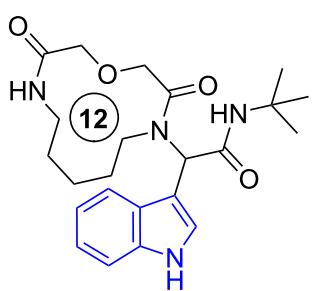

2b, $35 \%$
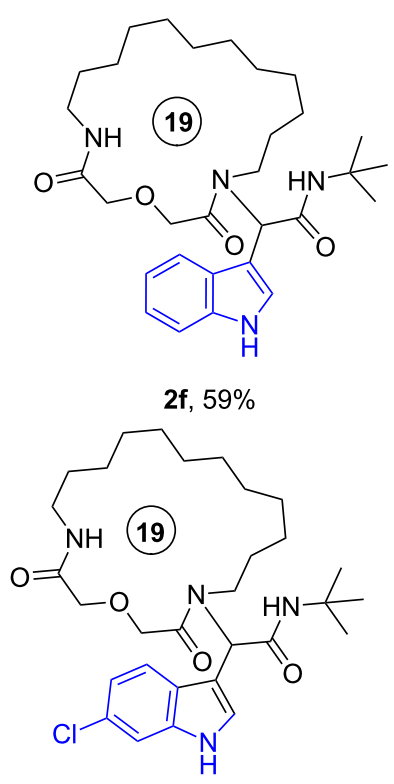

2j, $60 \%$

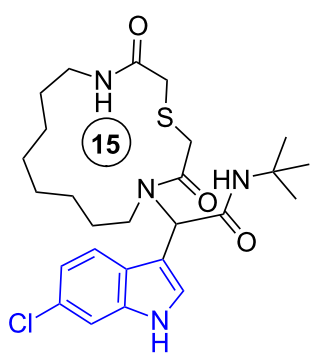

2n, $39 \%$

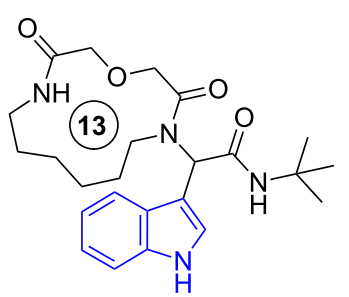

2c, $51 \%$

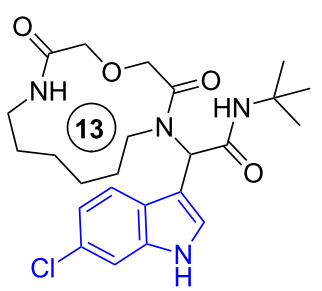

$2 g, 35 \%$

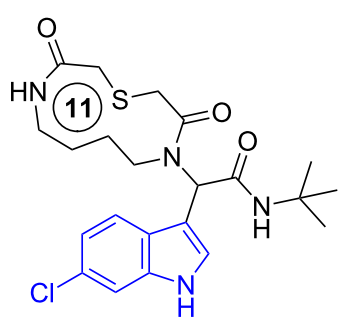

2k, $29 \%$

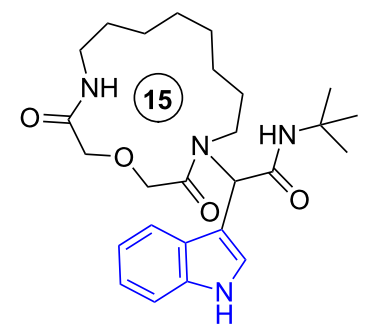

2d, $33 \%$

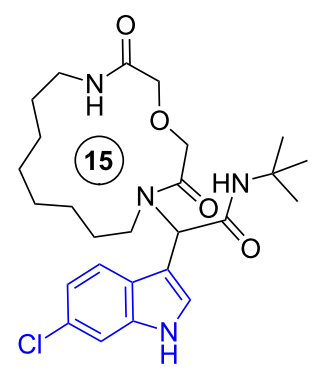

$2 \mathrm{~h}, 25 \%$ 
pot access to macrocycles $\mathbf{2 a - p}$ was achieved otherwise very difficult to synthesize in relatively good yields (29-60\%). 16 different indole-based macrocycles were synthesized with their size varying from $11-13,15,17$ and 19 atoms (Scheme 3).

\section{Biological evaluation}

Our previously introduced three-point pharmacophore model on mimicking the hot triad (Phe19, Trp23 and Leu26, $\mathrm{F}^{19} \mathrm{~W}^{23} \mathrm{~L}^{26}$ ) was the basis of the evaluation of the current derivatives as potent inhibitors [33]. The indole moiety could be used not only to constrain the two other substituents but also as an "anchor" mimicking the Trp23. The bulky tert-butyl group would mimic the Phe19 and the macrocyclic ring would fill the Leu26 subpocket as shown by our docking studies (Figure 1A,B, Figure S4 in Supporting Information File 1). Thus, extending our previous work [13], the Leu26 subpocket was probed by utilizing the different ring sizes and the different heteroatoms (oxygen or sulfur) of our macrocyclic library. In addition, the influence of the chlorine atom in the 6-position of the indole ring (Figure 1C) was examined. Macrocycles $\mathbf{2} \mathbf{a}-\mathbf{j}$ consist of an oxygen linker whereas $\mathbf{2 g}-\mathbf{j}$ bear also a chlorine atom in the
A

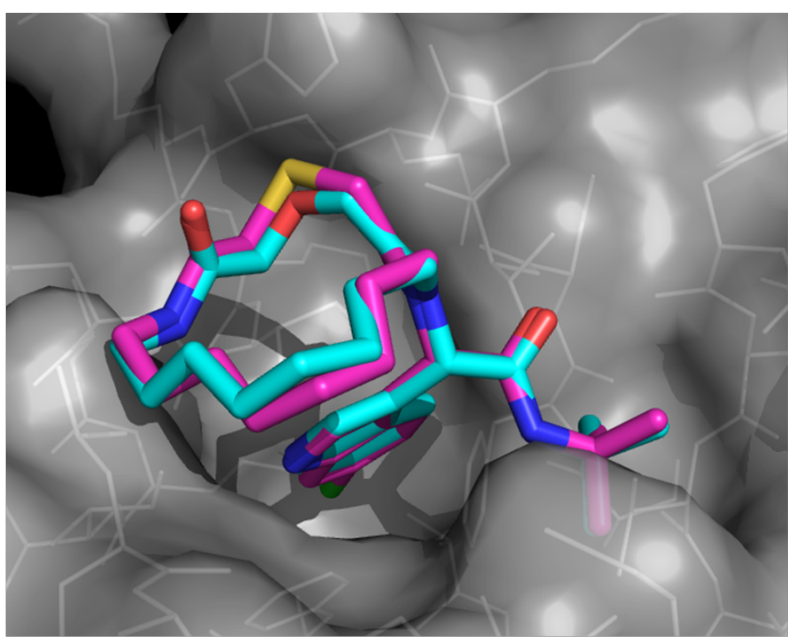

B

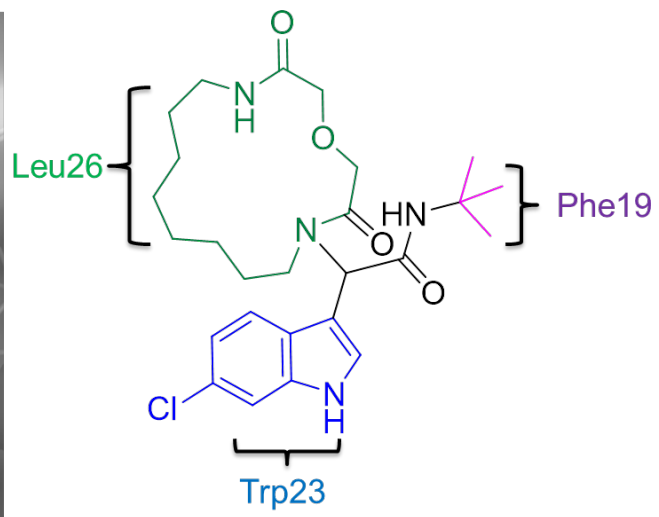

Dömling et al., Angew.Chem. 2017

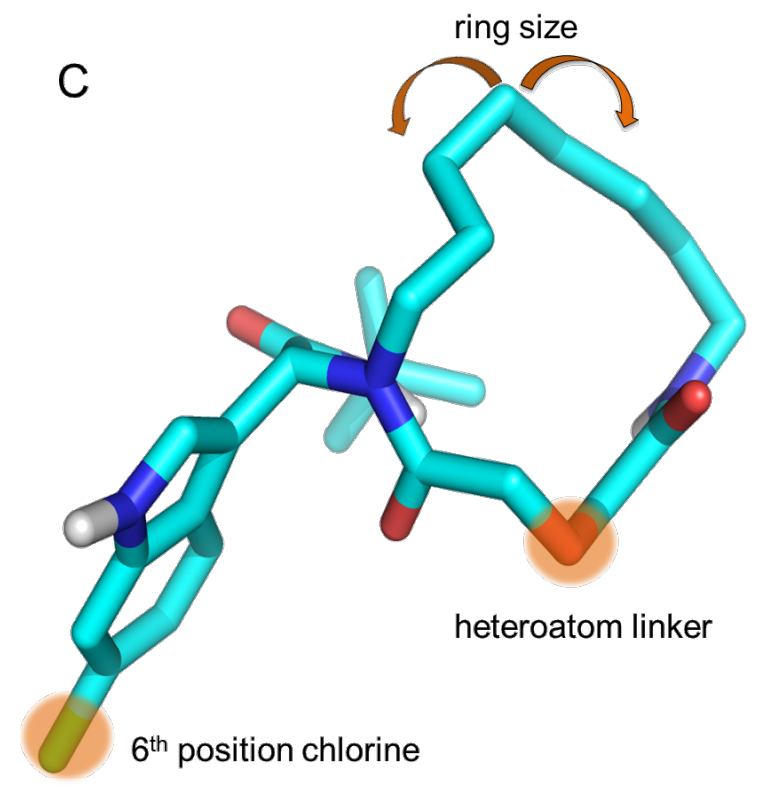

Figure 1: (A) Modeling of the macrocycle $\mathbf{2 h}$ (cyan sticks) and $\mathbf{2 n}$ (magenta sticks) into the MDM2 receptor (PDB ID: 1YCR); (B) 2D structure of $2 \mathbf{h}$ with the substituents targeting the subpockets of MDM2; (C) Analysis of the synthesized macrocycles probing the subpockets of MDM2 and expansion of the chemistry compared to previous studies [13]. 
6-position in the indole ring. Macrocycles $2 \mathbf{k}-\mathbf{p}$ incorporate both a sulfur linker and the chlorine on the indole ring (Scheme 3).

In order to exclude false positive hits, two biorthogonal assays were chosen; ${ }^{1} \mathrm{H},{ }^{15} \mathrm{~N}$ HSQC NMR and fluorescence polarization (FP, Table 1). FP assay was employed to determine the inhibitory affinities $\left(K_{\mathrm{i}}\right)$ of the derivatives against MDM2 as previously described [36]. Besides $2 \mathbf{h}\left(K_{\mathrm{i}}=2.3 \mu \mathrm{M}\right.$, $K_{\mathrm{d}}=12.1 \mu \mathrm{M}$ ), it was shown that $\mathbf{2 i}$ demonstrated a promising activity with a $K_{\mathrm{i}}$ of $5.5 \mu \mathrm{M}$. Furthermore, ${ }^{1} \mathrm{H},{ }^{15} \mathrm{~N}$ HSQC showed a $K_{\mathrm{d}}$ of $4.8 \mu \mathrm{M}$ (Table 1, Figure 2). Moreover, macrocycles $2 \mathrm{~g}$ and $2 \mathrm{n}$ demonstrated a $K_{\mathrm{d}}$ of $9 \mu \mathrm{M}$ and $17 \mu \mathrm{M}$, respectively (Table 1). With this preliminary analysis, it was found that a ring size of 15-17 atoms and an oxygen as the heteroatom linker improves the binding affinity. All the active macrocycles have a 6-chloro-substituted indole core. It is well established that at the bottom of the Try 23 pocket a hydrophobic small subpocket exists which is formed by Phe86, Ile103, Leu82 and Leu57. This pocket when filled with a smaller hydrophobic substituent such as $-\mathrm{Cl}$ boosts the inhibitor activity in accordance with literature [33].

Table 1: Measurement of $K_{\mathrm{i}}$ and $K_{\mathrm{d}}$ of the selected macrocycles based on FP and ${ }^{1} \mathrm{H},{ }^{15} \mathrm{~N}$ HSQC NMR assays, respectively. ${ }^{\mathrm{a}}$

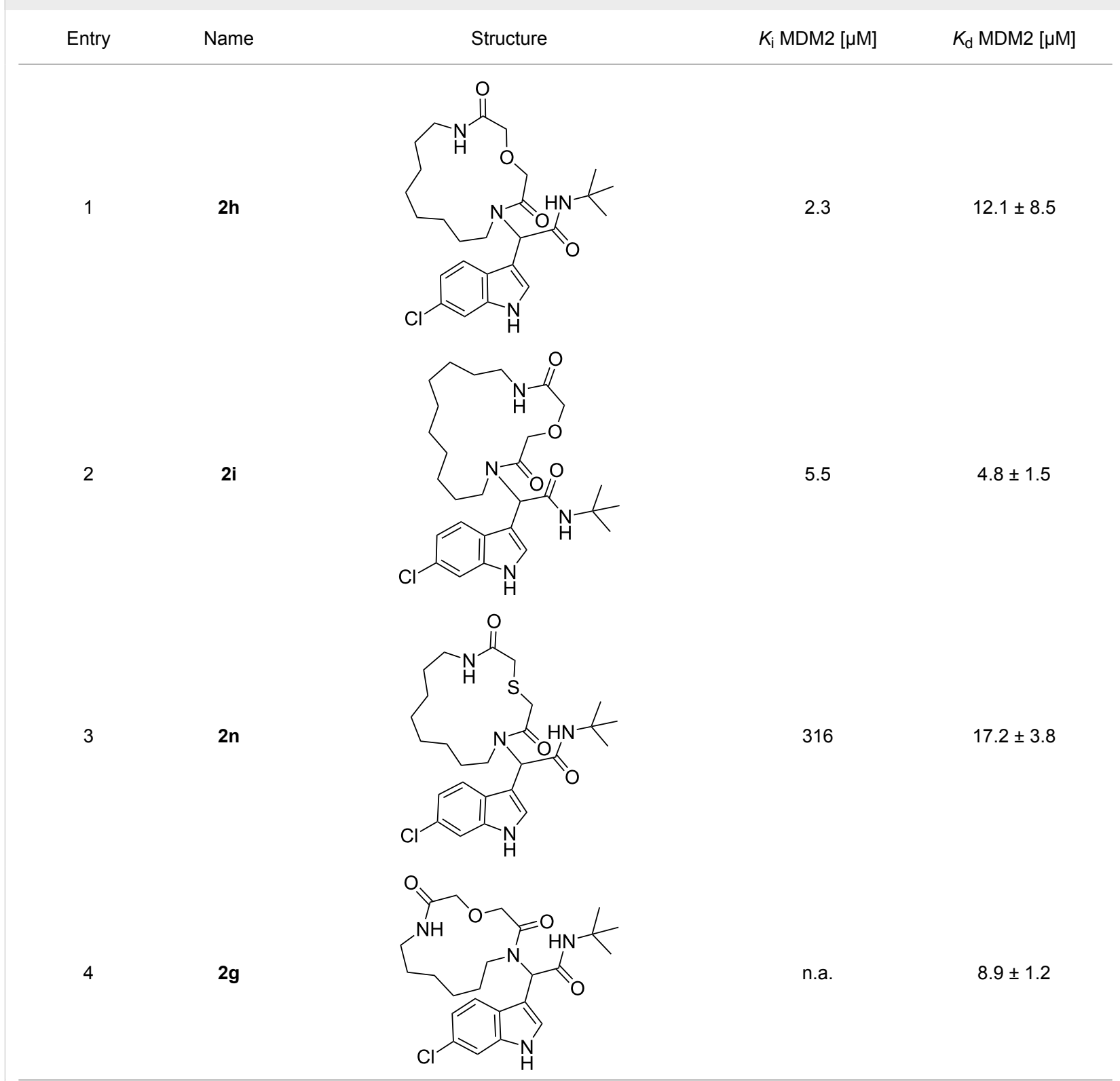

${ }^{a}$.a. no activity against MDM2 protein. $K_{\mathrm{i}}$ and $K_{\mathrm{d}}$ values were calculated based on fluorescence polarization binding and ${ }^{1} \mathrm{H},{ }^{15} \mathrm{~N}$ HSQC NMR assay, respectively. 

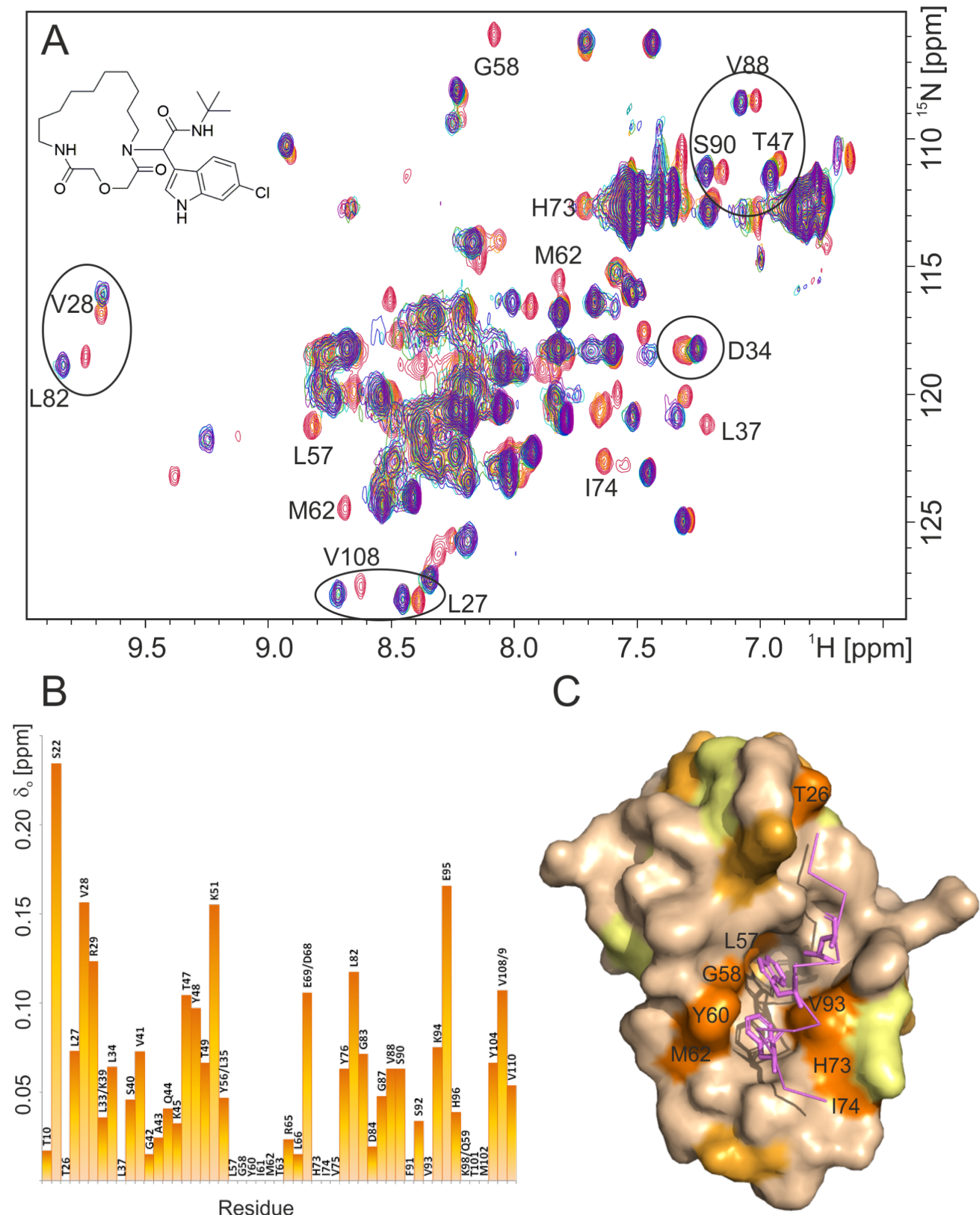

Residue

Figure 2: (A) Overlay of ${ }^{1} \mathrm{H},{ }^{15} \mathrm{~N}-\mathrm{HSQC}$ spectra of the reference MDM2 (red) and the titration steps with the 2i inhibitor. MDM2/2i ratios 4:1 (orange), 4:2 (yellow), 4:3 (green), 1:1 (light blue), 1:2 (blue), 1:5 (purple). Examples of most perturbed residues are labeled on the spectrum. (B) Normalized chemical shift perturbations $\left(\delta_{0}\right)$ of MDM2 residue (calculated according to Stoll et al. [41]). Residue with $\delta_{0}$ equal 0 are either despairing from MDM2 spectrum upon titration or cannot be identified. (C) Chemical shift perturbations plotted onto the structure of MDM2 (wheat); orange (despairing - indicating stronger binding), light orange $(>0.1 \mathrm{ppm})$, yellow $(0.05-0.1 \mathrm{ppm})$. Residues which disappear upon titration experiment are labeled on the Mdm2 surface. 


\section{Conclusion}

We effectively synthesized p53-MDM2 antagonists based on an artificial macrocyclic scaffold. 16 different derivatives were obtained and screened. The aforementioned artificial macrocycles combine the indole ring, a motif found in many bioactive molecules with the drug-like properties of a non-peptide macrocycle. We hypothesize that these chimeric derivatives of an indole and a macrocycle will offer new potential on specific PPIs and other postgenomic targets as it was demonstrated with the p53MDM2 interaction.

\section{Supporting Information}

\section{Supporting Information File 1}

Experimental procedures, analytical data, NMR spectra, fluorescence polarization binding assays, ${ }^{1} \mathrm{H},{ }^{15} \mathrm{~N}$ HSQC NMR spectra of ${ }^{15} \mathrm{~N}$-labeled MDM2 and computational modeling studies.

[https://www.beilstein-journals.org/bjoc/content/ supplementary/1860-5397-15-45-S1.pdf]

\section{Acknowledgements}

This research has been supported to (AD) by the National Institute of Health (NIH) (2R01GM097082-05), the European Lead Factory (IMI) under grant agreement number 115489, the Qatar National Research Foundation (NPRP6-065-3-012) and to (TAH) by Grant UMO-2014/12/W/NZ1/00457 from the National Science Centre, Poland. Moreover funding was received through ITN “Accelerated Early stage drug dIScovery" (AEGIS, grant agreement No 675555) and COFUND ALERT (grant agreement No 665250), Hartstichting (ESCAPE-HF, 2018B012) and KWF Kankerbestrijding grant (grant agreement No 10504).

\section{ORCID ${ }^{\circledR}$ iDs}

Constantinos G. Neochoritis - https://orcid.org/0000-0001-5098-5504 Maryam Kazemi Miraki - https://orcid.org/0000-0003-4834-1990 Eman M. M. Abdelraheem - https://orcid.org/0000-0002-9008-2729 Ewa Surmiak - https://orcid.org/0000-0002-4103-4675 Tad A. Holak - https://orcid.org/0000-0001-9369-6024

\section{References}

1. Giordanetto, F.; Kihlberg, J. J. Med. Chem. 2014, 57, 278-295. doi:10.1021/jm400887j

2. Davis, A. M.; Plowright, A. T.; Valeur, E. Nat. Rev. Drug Discovery 2017, 16, 681-698. doi:10.1038/nrd.2017.146

3. Scott, D. E.; Bayly, A. R.; Abell, C.; Skidmore, J. Nat. Rev. Drug Discovery 2016, 15, 533-550. doi:10.1038/nrd.2016.29

4. Villar, E. A.; Beglov, D.; Chennamadhavuni, S.; Porco, J. A.; Kozakov, D.; Vajda, S.; Whitty, A. Nat. Chem. Biol. 2014, 10, 723-731. doi:10.1038/nchembio.1584
5. Doak, B. C.; Zheng, J.; Dobritzsch, D.; Kihlberg, J. J. Med. Chem. 2016, 59, 2312-2327. doi:10.1021/acs.jmedchem.5b01286

6. Yu, X.; Sun, D. Molecules 2013, 18, 6230-6268. doi:10.3390/molecules18066230

7. White, C. J.; Yudin, A. K. Nat. Chem. 2011, 3, 509-524. doi:10.1038/nchem.1062

8. Failli, A.; Immer, H.; Götz, M. Can. J. Chem. 1979, 57, 3257-3261. doi:10.1139/v79-533

9. Gartner, Z. J. Science 2004, 305, 1601-1605 doi:10.1126/science.1102629

10. Jebrail, M. J.; Ng, A. H. C.; Rai, V.; Hili, R.; Yudin, A. K.; Wheeler, A. R. Angew. Chem., Int. Ed. 2010, 49, 8625-8629. doi:10.1002/anie.201001604

11. Koopmanschap, G.; Ruijter, E.; Orru, R. V. A. Beilstein J. Org. Chem. 2014, 10, 544-598. doi:10.3762/bjoc. 10.50

12. Iyoda, M.; Yamakawa, J.; Rahman, M. J. Angew. Chem., Int. Ed. 2011, 50, 10522-10553. doi:10.1002/anie.201006198

13. Madhavachary, R.; Abdelraheem, E. M. M.; Rossetti, A.; Twarda-Clapa, A.; Musielak, B.; Kurpiewska, K.; Kalinowska-Tłuścik, J.; Holak, T. A.; Dömling, A. Angew. Chem., Int. Ed. 2017, 56, 10725-10729. doi:10.1002/anie.201704426

14. Abdelraheem, E.; Khaksar, S.; Dömling, A. Synthesis 2018, 50, 1027-1038. doi:10.1055/s-0036-1590946

15. Janvier, P.; Bois-Choussy, M.; Bienaymé, H.; Zhu, J. Angew. Chem., Int. Ed. 2003, 42, 811-814. doi:10.1002/anie.200390216

16. Wessjohann, L. A.; Voigt, B.; Rivera, D. G. Angew. Chem., Int. Ed. 2005, 44, 4785-4790. doi:10.1002/anie.200500019

17. Wessjohann, L. A.; Rivera, D. G.; Vercillo, O. E. Chem. Rev. 2009, 109, 796-814. doi:10.1021/cr8003407

18. Abdelraheem, E. M. M.; Kurpiewska, K.; Kalinowska-Tłuścik, J.; Dömling, A. J. Org. Chem. 2016, 81, 8789-8795. doi:10.1021/acs.joc.6b01430

19. Beck, B.; Larbig, G.; Mejat, B.; Magnin-Lachaux, M.; Picard, A.; Herdtweck, E.; Dömling, A. Org. Lett. 2003, 5, 1047-1050. doi:10.1021/ol034077e

20. Liao, G. P.; Abdelraheem, E. M. M.; Neochoritis, C. G.; Kurpiewska, K.; Kalinowska-Tłuścik, J.; McGowan, D. C.; Dömling, A. Org. Lett. 2015, 17, 4980-4983. doi:10.1021/acs.orglett.5b02419

21. Abdelraheem, E. M. M.; Khaksar, S.; Kurpiewska, K.; Kalinowska-Tłuścik, J.; Shaabani, S.; Dömling, A. J. Org. Chem. 2018, 83, 1441-1447. doi:10.1021/acs.joc.7b02984

22. Abdelraheem, E.; Shaabani, S.; Dömling, A. Synlett 2018, 29 , 1136-1151. doi:10.1055/s-0036-1591975

23. Estrada-Ortiz, N.; Neochoritis, C. G.; Twarda-Clapa, A.; Musielak, B.; Holak, T. A.; Dömling, A. ACS Med. Chem. Lett. 2017, 8, 1025-1030. doi:10.1021/acsmedchemlett.7b00219

24. Abdelraheem, E. M. M.; de Haan, M. P.; Patil, P.; Kurpiewska, K.; Kalinowska-Tłuścik, J.; Shaabani, S.; Dömling, A. Org. Lett. 2017, 19, 5078-5081. doi:10.1021/acs.orglett.7b02319

25. Abdelraheem, E. M. M.; Madhavachary, R.; Rossetti, A.; Kurpiewska, K.; Kalinowska-Tłuścik, J.; Shaabani, S.; Dömling, A. Org. Lett. 2017, 19, 6176-6179. doi:10.1021/acs.orglett.7b03094

26. Gu, J.; Wang, B.; Liu, Y.; Zhong, L.; Tang, Y.; Guo, H.; Jiang, T.; Wang, L.; Li, Y.; Cai, L. Eur. J. Cancer 2014, 50, 1184-1194. doi:10.1016/j.ejca.2013.12.027

27. Brown, C. J.; Lain, S.; Verma, C. S.; Fersht, A. R.; Lane, D. P. Nat. Rev. Cancer 2009, 9, 862-873. doi:10.1038/nrc2763 
28. Cheok, C. F.; Verma, C. S.; Baselga, J.; Lane, D. P.

Nat. Rev. Clin. Oncol. 2011, 8, 25-37. doi:10.1038/nrclinonc.2010.174

29. Huang, Y.; Wolf, S.; Beck, B.; Köhler, L.-M.; Khoury, K.;

Popowicz, G. M.; Goda, S. K.; Subklewe, M.; Twarda, A.; Holak, T. A.; Dömling, A. ACS Chem. Biol. 2014, 9, 802-811.

doi:10.1021/cb400728e

30. Bista, M.; Wolf, S.; Khoury, K.; Kowalska, K.; Huang, Y.; Wrona, E.; Arciniega, M.; Popowicz, G. M.; Holak, T. A.; Dömling, A. Structure 2013, 21, 2143-2151. doi:10.1016/j.str.2013.09.006

31. Estrada-Ortiz, N.; Neochoritis, C. G.; Dömling, A. ChemMedChem 2016, 11, 757-772. doi:10.1002/cmdc.201500487

32. Neochoritis, C. G.; Wang, K.; Estrada-Ortiz, N.; Herdtweck, E.; Kubica, K.; Twarda, A.; Zak, K. M.; Holak, T. A.; Dömling, A. Bioorg. Med. Chem. Lett. 2015, 25, 5661-5666. doi:10.1016/j.bmcl.2015.11.019

33. Czarna, A.; Beck, B.; Srivastava, S.; Popowicz, G. M.; Wolf, S.; Huang, Y.; Bista, M.; Holak, T. A.; Dömling, A. Angew. Chem., Int. Ed. 2010, 49, 5352-5356. doi:10.1002/anie.201001343

34. Neochoritis, C.; Estrada-Ortiz, N.; Khoury, K.; Dömling, A. Annu. Rep. Med. Chem. 2014, 49, 167-187. doi:10.1016/b978-0-12-800167-7.00012-2

35. Popowicz, G. M.; Czarna, A.; Wolf, S.; Wang, K.; Wang, W.; Dömling, A.; Holak, T. A. Cell Cycle 2010, 9, 1104-1111. doi:10.4161/cc.9.6.10956

36. Czarna, A.; Popowicz, G. M.; Pecak, A.; Wolf, S.; Dubin, G.; Holak, T. A. Cell Cycle 2009, 8, 1176-1184. doi:10.4161/cc.8.8.8185

37. Huang, Y.; Wolf, S.; Koes, D.; Popowicz, G. M.; Camacho, C. J.; Holak, T. A.; Dömling, A. ChemMedChem 2012, 7, 49-52. doi:10.1002/cmdc.201100428

38. Surmiak, E.; Neochoritis, C. G.; Musielak, B.; Twarda-Clapa, A.; Kurpiewska, K.; Dubin, G.; Camacho, C.; Holak, T. A.; Dömling, A Eur. J. Med. Chem. 2017, 126, 384-407.

doi:10.1016/j.ejmech.2016.11.029

39. Shaabani, S.; Neochoritis, C. G.; Twarda-Clapa, A.; Musielak, B.; Holak, T. A.; Dömling, A. Med. Chem. Commun. 2017, 8, 1046-1052. doi:10.1039/c7md00058h

40. Koes, D. R.; Dömling, A.; Camacho, C. J. Protein Sci. 2018, 27 , 229-232. doi:10.1002/pro.3303

41. Stoll, R.; Renner, C.; Hansen, S.; Palme, S.; Klein, C.; Belling, A.; Zeslawski, W.; Kamionka, M.; Rehm, T.; Mühlhahn, P.; Schumacher, R.; Hesse, F.; Kaluza, B.; Voelter, W.; Engh, R. A.; Holak, T. A. Biochemistry 2001, 40, 336-344. doi:10.1021/bi000930v

\section{License and Terms}

This is an Open Access article under the terms of the Creative Commons Attribution License (http://creativecommons.org/licenses/by/4.0). Please note that the reuse, redistribution and reproduction in particular requires that the authors and source are credited.

The license is subject to the Beilstein Journal of Organic Chemistry terms and conditions:

(https://www.beilstein-journals.org/bjoc)

The definitive version of this article is the electronic one which can be found at:

doi:10.3762/bjoc. 15.45 